\title{
Reconstruction of the Liability of Juvenile's Action That Violates the Law in the Juvenile Criminal Justice System Based on Justice Value
}

\author{
Asep Hermawan ${ }^{1^{*}}$, Gunarto ${ }^{2}$, Sri Endah Wahyuningsih ${ }^{2}$ \\ ${ }^{1}$ Doctorate Student of Faculty of Law Sultan Agung Islamic University Semarang, Indonesia \\ ${ }^{2}$ Faculty of Law Sultan Agung Islamic University Semarang, Indonesia
}

DOI: $\underline{10.36348 / \text { sjhss.2020.v05i11.001 }}$ | Received: 13.10 .2020 | Accepted: 29.10 .2020 | Published: 03.11 .2020

*Corresponding author: Asep Hermawan

\section{Abstract}

The problem of juvenile dealing with the law is one of the problems surfaced in the effort to protect and to fulfill juvenile's rights in Indonesia. Currently, the problem is handled with Law No. 11 of 2012 concerning the Juvenile Criminal Justice System (SPPA) which regulates the judicial process for juvenile in conflict with the law, including juvenile in conflict with the law, especially regarding their assistance in the court. The existing problems show that the SPPA Law does not reflect the value of justice on the legitimacy of legal acts of juvenile in conflict with the law. This study uses a socio-legal research approach with data sources, namely primary data obtained in the field and relevant literature as a secondary data. The data analysis used was a descriptive-analytical method. The results the author's research shows that the protection of the legitimacy of juvenile's legal acts in conflict with the law in the juvenile criminal justice system in Indonesia has not shown the value of justice optimally because not all juvenile who undergo a judicial process in child criminal cases receive assistance from their parents or biological parents them, it is not uncommon for many parents to feel embarrassed to accompany the criminal justice process for their juvenile. From this, efforts are needed to reconstruct the legality of legal acts of juvenile, namely reconstructing and adding new constructs of Article 1 point 18 with new constructions and adding one new construction as point $18 \mathrm{a}$.

Keywords: Reconstruction, Juvenile, Criminal Justice, Justice Value.

Copyright () 2020 The Author(s): This is an open-access article distributed under the terms of the Creative Commons Attribution 4.0 International License (CC BY-NC 4.0) which permits unrestricted use, distribution, and reproduction in any medium for non-commercial use provided the original author and source are credited.

\section{INTRODUCTION}

Indonesia is a constitutional state, as explained in Article 1 paragraph (3) of the 1945 Constitution of the Republic of Indonesia (UUD NRI 1945) which states that "the State of Indonesia is a state of law". This is based on the explanation of the 1945 Constitution of the Republic of Indonesia that the Indonesian State is based on the law (rechstaat) and is not based on power alone (machstaat). Therefore, the state may not carry out its activities on the basis of mere power, but must be based on law [1].

The consequence of this is that Indonesia as a constitutional state is obliged to respect and fulfill the rights of its citizens, including the rights of the child as a citizen in Indonesia. Juvenile are one of the people who are vulnerable to acts of a discriminatory nature so that there is a need for legal action to provide protection and fulfillment to juvenile.
The purpose of the Indonesian State is basically contained in the fourth paragraph of the preamble to the 1945 Constitution of the Republic of Indonesia which states that "... to form a State Government of Indonesia that protects the whole Indonesian nation and all the blood of Indonesia ...". Efforts to protect every citizen in law and government have also been regulated on a constitutional basis in Article 27 paragraph (1) of the 1945 Constitution of the Republic of Indonesia which states that "All citizens are equal in law and government and are obliged to uphold the law and government without fail. there are exceptions".

The current problems caused by the lack of legal certainty in Indonesia can become an obstacle in realizing stable and fair political, social, and economic development. In short, if someone is asked what Indonesian law is on a certain subject, it is very difficult for that person to explain it with certainty, let alone how the law will be applied later [2]. 
This lack of legal certainty is evident in the case of someone who faces the Law $(\mathrm{ABH})$ who is classified as a child by his or her age, by Law No. 11 of 2012 concerning the Juvenile Criminal Justice System (UU-SPPA) but required to take legal actions.

Based on several definitions of juvenile from several laws and regulations in force in Indonesia, it can be said that the benchmark for the adult age limit depends on the statutory rules that govern it.

Juvenile are legal subjects and assets of the nation, as part of the younger generation juvenile who play a very strategic role as the next generation of a nation. In the Indonesian context, juvenile are the successor to the ideals of a nation's struggle. This strategic role has been recognized by the international community to give birth to a convention that essentially emphasizes the position of juvenile as human beings who must get protection for their rights [3].

Juvenile have rights that need to be protected and fulfilled both nationally and internationally. Internationally, juvenile's rights are regulated in the Convention on the Rights of Child UN General Assembly Resolution No. 44/25 dated November 20, 1989. This convention has been ratified by the Government of Indonesia with Presidential Decree No. 36, dated August 25 [4].

Problems that often occur regarding the protection of juvenile as legal subjects in Indonesia include problems regarding juvenile in conflict with the law, including juvenile in conflict with the law, juvenile who are victims, and juvenile who are witnesses.

Based on reports from the Indonesian Child Protection Commission (KPAI) from 2011 to 2019, the number of cases of juvenile dealing with the law reached 11,492 cases, far higher than reports of cases of juvenile entangled in health and narcotics problems (2,820 cases), pornography and cybercrime $(3,323$ cases), as well as trafficking and exploitation (2,156 cases). If examined, the case where juvenile must face the law by being a culprit of sexual violence tends to jump sharply. In 2011, there were 123 child sexual offenders. This number rose to 561 cases in 2014 , then dropped to 157 cases in 2016, and from mid-January to May 2019, the number of cases of juvenile facing the law as perpetrators of sexual violence reached 102 cases [5].

The data from the KPAI shows that juvenile as legal subjects need to get the widest possible opportunity to be able to grow and develop optimally, both physically, mentally, and socially. Moreover, childhood is a period of sowing seeds, building stakes, making foundations, which can also be called the formation of the character, personality, and character of a human being, so that they will have strength and ability and stand firm in life [6].

The problem, according to the author is that Indonesian Legal studies define "legally competent" to categorize an adult as being too pluralistic. Because the law regulates various kinds of definitions of legal capacity according to the context and purpose of each regulation. As a subject deemed incapable of law, juvenile have the right to receive protection in the judicial process. Because as subjects who are not yet "legally competent", juvenile are deemed unable to act independently in carrying out legal acts but they must be represented or assisted by other people.

To further emphasizes that, in the juvenile criminal justice system currently in effect in Indonesia, juvenile do not get this legal protection. Juvenile who face the law do not receive any assistance and interdiction required by law, especially civil law in legal acts committed by persons who are not yet adults or referred to as juvenile. Based on these problems, the researcher is interested in taking the problem to study it, and based on the background of the problems above, the researchers formulated the following problems:

1. Why is it that the law protection of the juvenile's conflict with the law in the juvenile criminal justice system process in Indonesia does not reflect justice yet?

2. How is the reconstruction of the law protection of the juvenile's conflict with the law in the juvenile criminal justice system process based on justice value?

\section{METHOD OF RESEARCH}

This study is a constructivist paradigm research that uses descriptive-analytical research. The method of approach used in research is socio-legal approach that is intended to study and examine the reciprocal relationship that is associated in real terms with other social variables [6].

Sources of data used include primary data obtained in the field and secondary data obtained from relevant literature among other things, in the form of: Legislation related to regional policies in poverty alleviation [7].

Research related to the socio-legal approach, namely research that analyzes problems is carried out by combining legal materials (which are secondary data) with primary data obtained in the field. Supported by first the secondary legal materials, in the form of writings from experts and civil law policies [8].

\section{RESEARCH RESULT AND DISCUSSION}

Reason Why the Law Protection of the Juvenile's Conflict with the Law In The Juvenile Criminal Justice System Process In Indonesia Does Not Reflect Justice Yet 
Children are legal subjects who have the potential for the advancement of the nation's future generations who will play a role in determining history in the future. The classification of the definition of children has a very broad aspect, a number of laws that regulate the status and treatment of children have differences regarding the limitations or definitions of the age to be categorized as a child.

The definition of a child nationally is based on the age limit of the child according to criminal law and in civil law. Internationally the definition of a child is contained in the United Nations Convention on the Right of the Child in 1989. United Nations Standard Minimum Rules for the Implementation of Juvenile Justice or United Nations Standard Minimum Rules for the Administration of Juvenile Justice ("The Beijing Rule") in 1985 and the 1948 Universal Declaration of Human Rights.

Nationally, the definition of a child according to legislation, which states that a child is someone who has not reached the age of 21 (twenty-one) years or is not married. There are also those who say a child is someone who is not yet 18 (eighteen) years old. Article 1 number 1 Law No. 23 of 2002 in conjunction with Law no. 35 of 2014 concerning Child Protection states that a child is a person who is not yet 18 (eighteen) years old, including children who are still in the womb, while Article 1 number 3 of Law No. 11 of 2012 concerning the Juvenile Criminal Justice System states that a child is a person who is 12 (twelve) years old, but not yet 18 (eighteen) years old who has not committed a criminal act.

This grouping is intended to identify with certainty the factors that cause responsibility for children, the Juvenile Criminal Court process starting from investigations, prosecutions, courts, and in carrying out court decisions in juvenile prisons, it is mandatory for educated officials to perform. specifically or at least know the problem about the child. Treatment during the juvenile criminal justice process must pay attention to the principles of child protection and still uphold the dignity of children without neglecting the implementation of justice, and not lowering the human value of children. For this reason, efforts are made to ensure that law enforcers are not experts in the field of legal science but especially honest and wise and have a broad and deep view of the weaknesses and strengths of humans and their communities.

The handling of children with problems through the administration of juvenile criminal justice is directed to adhere to the principle that the administration of juvenile criminal justice is an integral part of children's welfare efforts, which can provide assurance that every reaction to children in conflict with the law is always treated proportionally according to the environmental situation the perpetrator or his actions.

Efforts to provide legal protection are the obligations of the state, both during such trial and after serving the trial. Because every citizen has the right to protection from the law, especially children who still really need to undergo such legal cases. Child protection is sought by every person, parent, family, community, government, and state. Article 20 of Law No.35 of 2014 concerning Child Protection stipulates that "the State, government, society, family, and parents are obliged and responsible for the implementation of child protection" [9].

In Law No. 11 of 2012 concerning the Juvenile Criminal Justice System, the process of handling children in conflict with the law is closely related to law enforcement itself. Where in the Juvenile Criminal Justice System, the provisions for children, especially children as suspects in the criminal justice process, include all criminal procedural procedures, starting from investigations, investigations, and ending in the execution of crimes. In the process of investigating a child, it is not just looking for evidence and the cause of the incident, but also hopefully knowing the child's life background as a consideration in determining charges [10].

The Status of Law No. 11 of 2012 concerning the Juvenile Criminal Justice System has reached the legality procession, then the principles of criminal procedure law are increasingly prospective. Formulation of the provisions of Law No. 11 of 2012 concerning the Juvenile Criminal Justice System is an objective of the principles of law in the juvenile justice process in Indonesia.

The basic provisions of the Criminal Procedure Code for Children in Law No. 11 of 2012 concerning the Juvenile Criminal Justice System includes the following principles:

\section{The Not-yet Reached Adulthood principle}

The not-yet reached adulthood principle is a condition in the provisions to determine that a person can be processed in juvenile criminal justice. Regarding the criminal responsibility committed by children, this is regulated in Law no. 11 of 2012 concerning the Child Criminal Justice System. As explained in Article 1 child 3 , it is stated that children in conflict with the law are children aged 12-18 years. The responsibility for a child crime in the SPPA Law can be divided into 3 (three) categories, namely:

1. Children Under 12 Years old

2. Children between 12-14 years old

3. Children between 14-18 years old 


\section{The principle of freedom of inspection}

The provision of the principle of discretionary examination is meant by providing discretion for investigators, public prosecutors, judges, and officers of correctional institutions and/or probation/social worker officers to take actions or efforts to implement children's rights.

\section{Probation /Social Worker Principle}

The position of probation and social worker, which is translated as a social worker. It is regulated in article 1 point 4 of Law No. 11 of 2012 concerning SPPA. The provisions of this principle are prioritized for the translation system of a child's incapacity in a juvenile court.

The category of children in conflict with the law can be associated with juvenile delinquency, which is defined as children with social disabilities. As it is known, various kinds of opinions regarding juvenile delinquency as described according to Romli Atmasasmita who said that "Delinquency is an action or act committed by a child which is considered contrary to the legal provisions in force in a country and by the community itself is felt and interpreted as disgraceful act" $[11]$.

Regarding the protection of children in conflict with the law, Theodore Stated that child protection services are not sufficient to respond to reports of cases of child abuse and neglect [12].

The constitutional government's efforts to protect children from acts of a discriminatory nature are contained in Article 28B paragraph (2) of the 1945 Constitution of the Republic of Indonesia which states that "Every child has the right to live, grow and develop and has the right to protection from violence and violence. discrimination". So that in this case the state is obliged to provide protection to children as legal subjects from discriminatory actions, including children who are in conflict with the law.

Children in conflict with the law are entitled to a diversion process prior to the juvenile criminal justice process. Efforts to protect children in conflict with the law are carried out through Diversion in the form of transferring the settlement of children's cases from criminal justice processes to non-criminal justice processes. This diversion really needs special handling that aims to provide the best interests of children supported by adequate Police Human Resources (HR) and the availability of legal assistance, community counselors, professional social workers, and family/guardian and community support [13].

According to Sri Widoyanti, factors that can influence child crime include: a) broken home family; b) economic situation; c) community attitudes towards community members; d) population density; e) educational environment; f) the influence of film, television, and other entertainment; g) feelings of being left out by friends; $h$ ) the nature of the child himself.

In the process of solving juvenile criminal cases, law enforcers have been specifically determined, including investigators, public prosecutors, judges, and even the cassation judge. The juvenile criminal justice process has 5 stages, namely the stage of investigation, the stage of arrest and detention, the stage of prosecution and the stage of examination in court proceedings, and the stage of execution. The details of these stages are as follows:

\section{The Investigation Stage}

Investigation means a series of actions carried out by investigating officials in accordance with the means in law to seek and collect evidence, with the evidence making or becoming light of the criminal act that occurred and simultaneously finding the suspect or the perpetrator of the crime. Investigators in child criminal cases are child investigators who have met the requirements in accordance with this statutory regulation who specifically carry out investigations against children who are in conflict with the law. Investigators in child cases are obliged to ask for advice or advice from the Community Counselor after a crime has been reported or reported, even if deemed necessary Investigators can ask for advice or advice from educational experts, psychologists, psychiatrists, religious leaders, Professional Social Workers or Social Welfare Workers, and other experts. At this level investigators are obliged to seek Diversion, namely the transfer of settlement of children's cases from criminal justice processes to non-criminal justice processes which are carried out within 7 days after the investigation begins, while Diversion itself is carried out no later than 30 days after the Diversion begins. If the diversion is successfully carried out or an agreement is reached, according to article 29 paragraph 3 , the investigator submits a report on the Diversion Agreement along with the Diversion Agreement to the head of the district court to make a decision. However, if the Diversion fails then in accordance with Article 29 paragraph 4 the Investigator is obliged to continue the investigation and delegate the case to the Public Prosecutor by attaching the Diversion report and the social research report.

\section{The Arrest and Detention Stage}

The powers given to investigators are so broad. Derived from the authority given by the law, investigators have the right to reduce the freedom and human rights of a person, as long as this is still in favor of the legal basis of arrest and detention. This also exists in the procedural law for juvenile justice.

Article 30 of the Juvenile Criminal Justice System Law states that:

1. The arrest of a child is carried out for the purpose 
of investigation for a maximum of 24 (twenty four) hours.

2. Children who are arrested must be placed in a special service room for children.

3. In the case of a special service room for children, it must be carried out humanely by taking into account the needs according to their age.

4. The cost for each child placed in the LPKS is borne by the budget of the ministry that administers government affairs in the social sector.

In addition, in carrying out an investigation, investigators coordinate with the public prosecutor. This coordination is carried out within 1 X 24 hours from the start of the investigation. Detention of a child must not be carried out in the event that the child is guaranteed a parent/guardian, and/or institution that the child will not run away, will not lose or destroy evidence, and/or will not repeat the crime.

Based on Article 32 paragraph (2) of the Law on the Criminal Justice System for Children states that detention of a child can only be done with the following conditions:

1. The child is 14 (fourteen) years old or more.

2. Suspected of committing a criminal offense punishable by imprisonment of 7 (seven) years or more.

This provision is a new thing as a form of imposing an age limit for children who can be detained, given that those under 14 (fourteen) years of age are still vulnerable to being detained. The guarantee of children's rights must also be provided while the child is detained, in the form of physical, spiritual, and social needs of the child that must be fulfilled. To protect children's safety, placement in LPKS can be done.

\section{Prosecution Stage}

The next stage of the juvenile justice process is the prosecution process. Prosecution is an act of the Public Prosecutor (PU) to delegate a criminal case to the District Court (PN), which is authorized in matters and according to the manner regulated in the trial. Prosecution in a juvenile criminal procedure implies the act of the Child Public Prosecutor to delegate a juvenile case to a juvenile court with a request to be examined and decided by a juvenile judge in a juvenile trial. At this stage of the process, the public prosecutor who is given the task of prosecuting children who have committed a criminal act is the Child Public Prosecutor. This is in accordance with the provisions in article 41 paragraph 1 of the Juvenile Criminal Justice System Law.

The one who is given the task of prosecuting a child who has committed a criminal act is the Child Public Prosecutor. This is in accordance with the provisions in article 41 paragraph 1 of the Juvenile
Criminal Justice System Law.

In the event that there is no public prosecutor who meets the requirements stipulated in this law in the juvenile criminal case, then in accordance with Article 41 paragraph 3 the task of prosecution is carried out by the public prosecutor who carries out the task of prosecuting criminal acts committed by adults.

At this stage, the public prosecutor is still obliged to strive for Diversion. If the Diversion is successful, the public prosecutor will deliver the Diversion report along with the Diversion agreement to the head of the district court to make a decision. However, if the Diversion fails, the Public Prosecutor is obliged to deliver an official report of the Diversion and delegate the case to the court by attaching a social research report. This provision is contained in article 42 paragraph 3 and 4 of the Juvenile Criminal Justice System Law.4. Examination Stage at Court Session. In article 53 of the Juvenile Criminal Justice System Law, children are tried in a special room for children's court, the waiting room for children's trials is different from the waiting room for adult trials and the time for conducting children's trials takes precedence over adult sessions. In addition, the judge examines the case of children in a trial which is declared closed to the public, except for the reading of the verdict. In a children's trial, the judge is obliged to order a parent/guardian or companion, advocate, or other legal aid provider and social adviser to accompany the child. Even though in principle the criminal act is the responsibility of the child himself, but because in this case, the defendant is the child, the child cannot be separated by the presence of the parent/guardian. And if the judge does not involve parents or guardians, advocates or lawgivers, the child's trial is declared null and void, this is stated in article 55 paragraph 3 .

Trials in children's cases are closed to the public in order to create a calm and full atmosphere of kinship so that children can prioritize all events and feelings openly and honestly while they are running.

Basically, the juvenile trial is continued after the child is notified of the information given by the victim's child and / or the witness's child while the child is outside the court session. So before making a verdict, the judge gives the parent or guardian the opportunity and / or a companion to say something that is beneficial to the child. In certain cases, the child victim is given the opportunity by the judge to express his opinion on the case in question. Thus, the judge is obliged to consider the community research report from the social adviser before making a decision on a case. In the event that the social research report as referred to above is not considered in the judge's decision, the verdict is null and void. 
In the process of reading the court's decision, it is carried out in a trial open to the public and may not be attended by children. The identity of the child, victim's child, and / or witness's child must be kept secret by the mass media as referred to in Article 19 of the SPPA Law by only using the initials without pictures. For this reason, the court is obliged to provide a copy of the verdict on the day the judgment is read out to the child or advocate or other aid providers, social adviser, the public prosecutor, and the court is obliged to provide a copy of the decision no later than 5 days after the verdict was pronounced to the child or advocate or other legal aid providers, supervisor. community and public prosecutors.

\section{Execution Stage}

The execution stage is the stage where the child undergoes a sentence that has been handed down by a juvenile judge, if the child is sentenced to prison, the child will be executed to serve their sentence at the Children Special-Development Institute (LPKA) according to Law No. 11 of 2012 concerning the Juvenile Criminal Justice System still does not provide optimal justice for the protection of the legitimacy of legal acts committed by children in conflict with the law $(\mathrm{ABH})$. This is because the law is ambiguous, respects, and does well to him. Children are prohibited from acting disobediently to their parents. This disobedient act falls into the category of grave sin.

Based on the description above, if we compare positive (conventional) law with Islamic law, then positive law in this case, Law Number 11 of 2012 concerning the Criminal Justice System for Children, then the law is ambiguous, on the one hand, it states children to children who are in conflict with the law $(\mathrm{ABH})$ but on the other hand, children can be held accountable as adults, and are required to take legal actions like adults, and even have to undergo imprisonment if the child judge decides or imposes a sentence that $\mathrm{ABH}$ is proven to have committed a criminal act that can be imposed imprisonment. In contrast to Islamic law, the parents are responsible for the actions of the child, and only penal sanctions or fines can be imposed on $\mathrm{ABH}$ and the responsibility lies with the parents. Thus the UUSPPA is still ambiguous and has weaknesses.

\section{Reconstruction of the Law Protection of the Juvenile's Conflict with the Law in The Juvenile Criminal Justice System Process Based On Justice Value}

The child protection efforts that have been carried out by the government as mentioned above are inversely proportional to the government's efforts, particularly those implemented through Law No. 11 of 2012 concerning the Juvenile Criminal Justice System, as well as Law No. 17 of 2016 concerning Stipulation of Government Regulations in Lieu of Law No. 1 of 2016 concerning the Second Amendment to Law No.
23 of 2002 concerning Child Protection into law. ABH during the juvenile trial process, $\mathrm{ABH}$ must pass through legal action, namely by signing as a legal act which should only be done by adults, as is the case in the Law on Notary Position to be able to appear before a notary to make a notary deed only the age limit is must be fulfilled is 18 (eighteen) years old, and the age limit in the provisions referred to, only applies in making a notary deed, but to carry out legal actions in matters of or relating to the relinquishment of land rights, the National Land Agency requires that they are 21 (twenty-one) year old as adults based on the colonial legacy of the Civil Code (KUH Per).

Law Number 11 of 2012 concerning the Criminal Justice System for Children does not regulate maturity, and the Penal Code itself which regulates maturity, the age requirement can apply for maturity is 18 (eighteen) years old, meaning that the child as regulated in Law Number 11 of 2012 Regarding the Child Criminal Justice System, it is still a child and cannot be considered as an adult or maturity as stipulated in the Civil Code.

Provisions regarding a person's ability to take legal actions are regulated in various ways in Indonesian legislation. Things like this create confusion in determining when a person is declared competent to perform legal actions. Legal action always requires that a person be declared competent to carry out legal actions. A legal act with other legal actions provides different conditions for a person to be declared capable of acting lawfully.

The definition of a child and the age limit held by children differ according to applicable laws in Indonesia, including:

a) Law No. 1 of 1974 concerning Marriage requires a marriage age of 16 years for women and 19 years for men.

b) Law No. No. 41979 concerning Child Welfare defines a child as 21 years old and has never been married.

c) Law No. 3 of 1997 concerning Juvenile Court defines a child as a person who in the case of a delinquent child is eight years old, but has not yet reached 18 years of age and has never been married.

d) Law No. 39 of 1999 concerning Human Rights states that a child is someone who is not yet 18 years old and has never been married.

e) Law No. 23 of 2002 concerning Child Protection is someone who is not yet 18 (eighteen) years old, including children who are still in the womb.

f) Law No. 13 of 2003 concerning Employment allows a working age of 15 years.

g) Law No. 20 of 2003 concerning the National Education System imposes a 9-year compulsory education, which connotes children aged 7 to 15 years. 
Likewise, the minimum age limit for criminal responsibility (criminal) does differ between countries. This depends on how a country defines juveniles Delinquent child is also a synonym for juvenile delinquent, according to the black's law dictionary, means a child who is guilty of a criminal treatment which is usually punished by special laws that do not concern adults [17].

Reflecting on the existing cases, it can be seen that the age of 8 years is still too early for children to be responsible for their actions. At that age, children still do not understand what is being done, they cannot distinguish what is right and what is wrong. The legal description he does is a reaction from his social and individual conditions, including as an expression of the psychological transition problems he is experiencing, or more as a child's mis-adjustment of the difficult or unpleasant situations he is facing. Many believe that this delinquency will disappear once the child reaches adulthood and if the external factors he is facing are eliminated, it is even more strongly believed that no matter how well a judicial system operates, it still allows harm to children, due to their vulnerability due to her age. Due to their psychological and physical limitations, they are also very easily affected by their surroundings.

In connection with the legal actions of children in the juvenile criminal justice system have not fulfilled the value of justice, because the law (Law Number 11 of 2012 concerning the Criminal Justice System for Children) forces children into law or for the law in the form of committing legal acts that are contrary to laws and regulations. other invitations (laws) that apply, especially Article 1 point (18) of Law Number 11 of 2012 concerning the Juvenile Criminal Justice System, according to the author does not have legal clarity and certainty, theoretically or practically, so that article will be the author of the reconstruction so that it has a sense of justice and legal certainty for $\mathrm{ABH}$ so that "law is for humans $(\mathrm{ABH}) "$, not the other way around [18].

Article 1 point (18) of Law No. 11 of 2012 concerning the Juvenile Criminal Justice System, based on the theories that the author has put forward and based on the research results obtained, the authors propose a reconstruction of the law are divided into 2 (two) points with the following phrases:

1. Article 1 point (18), the phrase which originally reads "A companion is a person who is trusted by the child to accompany him during the criminal justice process"

is enhanced to become:

"A companion is a person who is trusted by the child to accompany him or her during the criminal justice process and can act as a guardian of the child. If the child is a rock or the parent refuses to accompany the child".
2. Article 1 point (18) is added with one more item to become point $18 \mathrm{~A}$, with the phrase suggested that "Child companion is proposed and appointed by the Head of the Community Service based on the results of the Community Research from the Community Advisor". The addition of point 18 is related to not having clarity about what is meant by a companion, and who can determine or appoint an assistant.

\section{CONCLUSION}

1. Protection of the legality of legal action against children in conflict with the law during the juvenile criminal justice process has not shown optimal justice because children who are still not legally mature should act independently in committing legal acts. Basically, children still have implications for the future. Not all children who are faced with the law during the child criminal justice process have parents and or even their own biological parents often do not want to be responsible because they feel shame and shame for their child's actions. Article 1 point 18, which requires a child to have a companion, does not explain that the companion is the guardian of the child so that the legality of his legal action can be declared legally valid.

2. Reconstruction of the legitimacy of children's legal acts in conflict with the law in undergoing justice-based juvenile justice processes is by reconstructing and adding new constructs of Article 1 point 18 with new constructions and adding this new construction as point $18 \mathrm{a}$.

\section{REFERENCE}

1. Kansil, C. S. T. (1986). Hukum Tata Negara Republik Indonesia. (Jakarta: Bina Aksara), 86.

2. Ade, M. S., \& dan Satrio, J. (2010). Penjelasan Hukum tentang Batasan Umur. (Jakarta: Nasional Legal Reform Program) 2.

3. Ruben, A. (2005). Upaya Penyelesaian Masalah Anak yang Berkonflik dengan Hukum di Kota Palembang. Jurnal Simbur Cahaya Nomor, 27(10), 24.

4. Wiyono, R. (2019). Sistem Peradilan Pidana Anak di Indonesia. (Jakarta: Sinar Grafika), 34.

5. Muhammad, S. (2020). Kasus Anak Berhadapan dengan Hukum Terbanyak Dilaporkan ke KPAI, accessed on http://www.gresnews.com/berita/isu_terkini/117 602-kasus-anak-berhadapan-dengan-hukumterbanyak-dilaporkan-ke-kpai/, in 7 October 2020.

6. Maidin, G. (2008). Perlindungan Hukum Terhadap Anak dalam Sistem Peradilan Pidana Anak di Indonesia. (Bandung: Refika Aditama), 1 .

7. Mukti, F. N. D. (2010). Dualisme Penelitian Hukum Normatif dan Empiris, Pustaka Pelajar, Yogyakarta, 192. 
8. Soerjono, S. (1984). Pengantar Penelitian Hukum, (Jakarta: UI Press), 52.

9. Pratama, R., Sulastri, S., \& Darwis, R. (2017). Perlindungan Terhadap Anak Yang Berhadapan Dengan Hukum. Prosiding Penelitian dan Pengabdian kepada Masyarakat. 2. 10.24198/jppm.v2i1.13229.

10. Abdurrachman, H., Sudewo, F., \& Permanasari, D. (2015). Model Penegakan Hukum Anak yang Berhadapan dengan Hukum dalam Proses Penyidikan. Pandecta: Research Law Journal. 10:167. 10.15294/pandecta.v10i2.4951.

11. Romli, A. (1977). Peradilan Anak Di Indonesia. (Bandung: Mandar Maju), 15.

12. Cross, T., Goulet, B., Helton, J., Lux, E., \& Fuller, T. (2020). What Happens When A Child Is Reported To Child Protective Services?. 10.13140/RG.2.2.24240.58885.
13. Abdurrachman, H., Sudewo, F., \& Permanasari, D. (2015). Model Penegakan Hukum Anak yang Berhadapan dengan Hukum dalam Proses Penyidikan. Pandecta: Research Law Journal. 10; 167. 10.15294/pandecta.v10i2.4951.

14. Darji D., \& dalam Muhamad, E. (2012). Filsafat Hukum Refleksi Kritis Terhadap Hukum, PT. Rajagrafindo Persada, Jakarta, 229.

15. Arief, G. (2004). Masalah Korban Kejahatan (Kumpulan Karangan), PT. Buana Ilmu Populer, Jakarta, 246.

16. Purniati, T. T. Analisis Situasi Sistem Peradilan Pidana Anak (Juvenile Jusctice System) Di Indonesia, Unicef, Jakarta, 204.

17. Bryan, A. G. (1999). Black's Law Dictionary, West Group, St. Paul, 232.

18. Satjipto, R. (2005). Hukum Progresif, Hukum Yang Membebaskan, Jurnal Hukum Progresif, PDIH Semarang, 1(1):5. 